Vol. 16 No. 1 - April 2016

\title{
American Dreams Represented through the Color in Fitzgerald's The Great Gatsby
}

\author{
Monica Federica Ghiotto \& Hirmawan Wijanarka \\ English Letters Department, Sanata Dharma University, Yogyakarta \\ hir101@usd.ac.id
}

\begin{abstract}
This article aims at observing F. Scott Fitzgerald's The Great Gatsby that was first published in 1925, a novel about a man named Gatsby who wants to get his love back by making effort to be a rich person. The prominent color symbols and how the symbols represent the American Dream are the main concern of this article. Two objectives are set to guide the study of the novel. The first is to explai the color symbols that are prominent in the study, and the second is to analyze how the color symbols represent the American Dream. From the analysis, there are three prominent colors presented in the novel: green, white and gold. Green that symbolizes the American Dream of the better life and happiness can be seein in the green light, the green leather conservatory, the greenhouse, the apple-green shirts, the green jersey, the green card, the green Sound, and the green breast of the new world. White symbolizes the American Dream of of fame, wealth, perfection, innocence, and success. This color can be seen in the white palaces of fashionable East Egg, the white dress, the white windows, the white roadster, the white cards, and the white flannel suits. Gold that symbolizes the American Dream of material prosperity can be seen in the golden arm, the golden shoulder, the gold-colored tie, and the toilet set of pure dull gold color.
\end{abstract}

Key words: American dream, green, white, gold.

\section{Introduction}

Fitzgerald beautifully employs symbols in The Great Gatsby. He uses several colors to help emphasize the ideas of American Dreams, the dreams of having successful life in America. As stated by Maia Samkanashvili (2013: 31), symbols are an important and integral part of what makes it a great novel. She said that in this novel Fitzgerald was also painter who made his writing very bright, as he mostly uses purecolors, not shades. These colors give the reader greater insight into the characters and their lives. Symbolism in The Great Gatsby reflects what life in the 1920's was like through Fitzgerald's eyes.

Fitzgerald skillfully portrays the issue of American Dreams: how people perceive, behave, and respond to the dreams. Everybody has dreams (long held ambitions or ideals) and they certainly try to atchieve them in their own ways. Many people dream of achieving wealth, position, prosperity and honor, and those who achieve their dreams are labelled successful. Society highly respects and acknowledges those who can achieve their dreams, and this makes people even more enthusiastic about achieving their dreams.

During Gatsby's era, America is wellknown as the place that gives everybody abundant chances to fulfill their dreams. Degler (1962:274) mentions that between 1820-1920 great waves of Europeans flooded American land. He says that 38 million people came to the United States. America had been the goal of those who were bold enough to take a second chance. In the novel Fitzgerald identifies the characteristics of Americans in 1920s as follows: 
May one offer in exhibit the year 1922! That was the peak of the younger generation, for though the Jazz Age continued, it became less and less an affair of youth..... A whole race going hedonistic, deciding on pleasure... The word jazz in its progress towards respectability has mean first sex, then dancing then music. In any case, the Jazz Age now raced along under its own power, served by great filling stations full of money... It was borrowed time anyhow - the whole upper tenth of a nation living with the insouciance of grand dukes and casualness of chorus girls... (1965: 9 - 19).

There ar two points this article is trying to focus: (1) the presentation of the prominent colors found in the story, and (2) how these prominent colors represent the American Dream.

\section{Symbols in Literary Works}

A symbol is something that means more than what it is; an object, person, situation, or action that in condition to its literal meaning suggests other meanings as well. According to Stanton (1965:32), readers can find symbols in a work of literature by paying attention to the clues that the author gives, for instance by providing conspicuous details, i.e. by describing it more fully than its factual importance deserves, by making it unusual for no apparent reason, by mentioning it in the title, or by some other means. Further Stanton explains that

Symbol may be anything from an egg to the story's setting: a single object, a physical type of object, a physical substance, a shape, a gesture, a color, a sound, a fragrance. They may represent a facet of human personality, futile ambition, the romanticism of youth and so on (1965:31).

Similar to the above ideas, Guth (1997:189) states that a symbol may come as an image that has meaning beyond itself, which can be in a form of a particular detail, a character, or an incident that has meaning beyond its literal role in the narrative.
What readers need to do is to trust the story because when an author wants to mark an object or detail with symbolic significance, he or she will indicate his or her intended meaning, either explicitly or implicitly (Rohrberger and Wood, 1971:16). Therefore, readers' willingness and ability in examining every detail in the story is needed to find symbols. In addition to examining details, readers must also notice any pattern or linking between the details that the author gives since it is key to reveal the symbolism.

The ability to interpret symbols is indeed essential for a full understanding of a literary text. Readers should always be alert for symbolic meanings but, at the same time, should observe some cautions. Firstly, the story itself must finish a clue that a detail is to be taken symbolically. The clue can be seen from the emphasis, repetition, or position of the word. Secondly, the meaning of the literature symbol must be established and supported by the entire context of the story. This means that the whole context of the story must support the meaning of the word, which is taken as symbol. Thirdly, to be called as a symbol is something more than the representative of class or type. Fourthly, a symbol may have more than one meaning. It may suggest a cluster of meanings. However, these meaning have to be controlled by the context of the story (Arp and Johnson, 1998: 289-291).

Classifying symbols into types, Myers and Simms (1989:198) distinguish symbols into three kinds: (1) the archetypal symbol in which a natural object refers to a limited number of interpretations that transcend cultural barriers; (2), the general symbol which appeals to a smaller audience but which contain more associate meaning; and (3) the private (authorial) contextual symbol which is created in the author's imagination and convey any number of meanings in the guiding context.

Another classification of symbols comes from Roberts and Jacobs (1991:327). There are two kinds of symbol. The first is a conventional or universal symbol, which can be defined as -ideas or emotions that the writer and the reader share in common as a 
result of their social and cultural heritage. A conventional or universal symbol, therefore, is likely to be recognized by most people because it has been used commonly as can be conveyed in the word. The second kind of symbol is called private, authorial or contextual symbol. This kind of symbol can defined as -the object and descriptions that gain their symbolic meaning within the context of the specific work of fiction. Thus, a contextual symbol will only occur in a particular literary work due to the fact that this kind of symbol has value only for a particular people, nation, or culture. As a consequence different symbols may have quite different meanings in different contexts.

\section{Colors as Symbols}

According to Zettl, a color can serve as a powerful visual element that acts as a code that provides a deeper level of meaning to those who are able to interpret the signs. Consider how much less information a map would provide if it were in black and whitethe different types of road would not be so distinguishable, and you may even confuse contour lines for rivers and streams. The simple yet effective use of color provides a visual code that allows us to correctly interpret the image that we are seeing (1999:74).

Green, for example, may mean nature, fertility, confidence, and desirability. It is usually associated to money, nature, jade jewelry. White means clean, pure, elegant, and accomplishment. Wgite is frequently associated to jewelry, snow, flowers, Brahman (highest caste), angel. Gold means luxury, wealth, royalty, light, luxury, money, and prestige. For example jewelry, pirate treasure, coins, colors of the royal crown and church decorations are represented in gold color (Bortoli and Maroto, 2001: 15).

Vaughn-Kelso, Carothers, and Breese (2005: 87-96) state that green represents calming, sympathy, victory, honor, hope, faith, and peace, fertile. Grey represents sadness and depression. Blue represents sadness, and illusion. Pink represents love and feminine. Black represents death and mystery. Yellow represents jealousy, cowardice, and sickness.
White represents pure love, purity, and perfection. Brown represents unsettling and materialistic. Gold represents comfort, wealth and optimism. Silver represents beauty

\section{The American Dreams}

The idea of an American Dream is older than the United States. It dated back in 1600s when people began to come with all sorts of hopes and aspirations for the new and largely unexplored continent. They focused on owning land and establishing prosperous business, which would theoretically generate happiness. The term of American Dream is used in a number of ways, but essentially the American Dream is an idea, which suggests that all people can succeed through hard work, and that all people have the potential to live a happy, and successful life. The American Dream is an idea which suggests that all the people can succeed through hard work, and that all people have the potential to live happy, successful lives (Smith, 2011: 1). The Declaration of Independence clearly protects The American Dream: "We hold these truths to be self-evident, that all men are created equal, that they are endowed by their Creator with certain unalienable Rights, that among these are Life, Liberty and the pursuit of Happiness."

Cullen (2003: 5) adds that the American Dream is not a single concept, but rather comprises various ideals that can even be contradictory. The American Dream has become a kind of national motto or belief, and this belief has become the hopes and aspirations of Americans for generations. Matthew Warshauer (2003), a Professor of History at Central Connecticut State University, says that American Dreams are diverse. In most cases American Dreams can be categorized into three categories: dreams of success, dreams of fame, and dreams of wealth. Americans focus their efforts on hard work in order to achieve the American Dreams. 


\section{The Prominent Color Symbols in The Great Gatsby}

\section{Green}

Green is very important and it is one of the prominent color symbols that are mentioned many times in the story. The color green is mentioned from the first chapter to the last chapter (16 times). Green light is mentioned when the narrator, Nick, sees Gatsby for the first time and tries to call him but decides not to disturb him, because Gatsby looks seriously glancing at something. Nick finally figures that it is the green light across, at the end of the dock.

I decided to call to him. Miss Baker had mentioned him at dinner, and that would do for an introduction. But I didn't call to him, for he gave a sudden intimation that he was content to be alone - he stretched out his arms toward the dark water in a curious way, and, far as I was from him, I could have sworn he was trembling. Involuntarily I glanced seaward - and dis- tinguished nothing except a single green light, minute and far away, that might have been the end of a dock (19).

The green light shows the hope that Gatsby wants to achieve. It turns out that the green light is the light that comes from Daisy's house, the woman whom Gatsby loves. When Gatsby finally brings her to see his house, Gatsby tells Daisy that the he always looks at the green light across the bay, Daisy's house. And when Nick and Gatsby are going for for lunch, they ride Nick's luxurious car whose conservatory is made of greed leather. "Sitting down behind many layers of glass in a sort of green leather conservatory, we started to town" (50).

Green also means fertile. It can be seen when Nick invites Daisy for teatime. The day before, Gatsby orders his gardener and all the workers to make the house more beautiful and green. Gatsby wants everything to look perfect when Daisy comes in the tea party. He wants to impress her. Green which indicates fertility is also symbolizes the love of Gatsby for Daisy. Just as the greenhouse which has lots of beautiful, fresh flowers, and garden, he hopes he begins his new relationship with Daisy. The other green colors which also mean hope can be seen on the Apple-green shirt and green jersey.

The novel also mention the green Sound when Gatsby, Nick, Tom, Daisy, and Jordan are having lunch at Tom and Daisy's house. Tom tells everyone to go to the verandah and see outside because that day is really a hot day.

I went with them out to the veranda. On the green Sound, stagnant in the heat, one small sail crawled slowly toward the fresher sea. Gatsby's eyes followed it momentarily; he raised his hand and pointed across the bay.

"I'm right across from you."

"So you are." (91)

The green Sound refers to the green water related to the sea. The green means the hope of Gatsby to be with Daisy even though there is a distance between them. It is shown when he points across the bay and tells that he is right across from the Buchanan's house, which means that he tries to say that he is already close to Daisy.

Green breast of the new world symbolizes hope for something to happen. Nick mentions about the situation when he spends the night in Long Island. $\mathrm{He}$ is thinking about Gatsby and he describes the situation in Long Island where Gatsby lives.

Most of the big shore places were closed now and there were hardly any lights except the shadowy, moving glow of a ferry- boat across the Sound. And as the moon rose higher the ines- sential houses began to melt away until gradually I became aware of the old island here that flowered once for Dutch sail- ors' eyes-a fresh, green breast of the new world (138).

Nick describes Long Island as a fresh green breast. It refers to the whole place in Long Island, a place where Dutch sailor would like to make a new world. From this explanation, it is shown that green here means the hope to have a great opportunity 
to make a settlement in Long Island in order to get a better life or a better future.

\section{White}

White is mentioned many times in the story. It is closely related to wealth, innocence, perfection and success. White is presented in white palaces, white dress, white windows, white roadster, white card, and white flannel suits. In chapter one, " the white palaces of fashionable East Egg" means something that has been achieved by the Buchanan. Palaces show the richness of the Buchanan. East egg is where the Buchanan lives. It is mentioned in the story when Nick describes the mansion of the Buchanan's in the east egg.

Across the courtesy bay the white palaces of fashionable East Egg glittered along the water, and the history of the summer really begins on the evening I drove over there to have dinner with the Tom Buchanans.... (7)

White palaces indicate wealth. It is as a big mansion that belongs to the Buchanans. Tom and Daisy are from the upper-class society and they live in luxurious lifestyle. Nick describes the mansion of the Buchanans again when he goes at their house for the first time to have a lunch together and meet his cousin, Daisy. One of the dominant colors of the big and luxurious house is white. White is also mentioned when Nick describes the windows inside the house of the Buchanans.

We walked through a high hallway into a bright rosy-colored space, fragilely bound into the house by French windows at either end. The windows were ajar and gleaming white against the fresh grass outside that seemed to grow a little way into the house. (9)

White dress symbolizes the wealth and success. In the story, it is described when Nick comes to the Buchanan's house to meet Daisy. He sees Daisy and Jordan wearing white dresses. "They were both in white, and their dresses were rippling and fluttering as if they had just been blown back in after a short flight around the house" (9). Jordan is an upper class man, a famous golf athlete; and Daisy is a successful and rich woman who lives in a big mansion, married a very rich man, and has a perfect life. White dress is again mentioned when Jordan talks about Daisy when she was eighteen years old. Jordan says that Daisy was wearing white dress meeting Gatsby.

She was just eighteen, two years older than me, and by far the most popular of all the young girls in Louisville. She dressed in white, and had a little white roadster, and all day long the telephone rang in her house and excited young officers from Camp Taylor demanded the privilege of monopolizing her that night. -Anyways, for an hour! (58).

White dress is associated with perfection, wealth, and fame. And in many other occasions, Daisy and Jordan wear white dresses.

White flannel suits represent Gatsby's wealth. Gatsby wears the white flannel suit when he meets Daisy for the first time. "An hour later the front door opened nervously, and Gatsby, in a white flannel suit, silver shirt, and gold- colored tie, hurried in" (65). He wants to impress Daisy with material achievements.

\section{Gold}

Gold color, first of all, represents power, success, and achievement. It can be seen in the following description about Jordan:

"With Jordan's slender golden arm resting in mine, we descended the steps and sauntered about the garden (35)."

It was dark now, and as we dipped under a little bridge I put my arm around Jordan's golden shoulder and drew her toward me and asked her to dinner (62).

For a golf athlete, the power of the swing and the success as a golf athlete really depends on the arm. Her shoulder and her arms are the key that might lead her to be a famous golf athlete. 
Gold-colored tie can be interpreted as the symbol of wealth. Gatsby wears it when he meets Daisy. He wants to show that he is a high-class man. "An hour later the front door opened nervously, and Gatsby, in a white flannel suit, silver shirt, and gold- colored tie, hurried in. He was pale, and there were dark signs of sleep- lessness beneath his eyes" (65). Gold color can be seen again in Gatsby's toilet set which is of pure dull gold.

His bedroom was the simplest room of all- xcept where the dresser was garnished with a toilet set of pure dull gold. Daisy took the brush with delight, and smoothed her hair, whereupon Gatsby sat down and shaded his eyes and began to laugh (71).

According to Bortoli and Moroto (2001:15), gold is the color used for money and jewelry. The explanations above lead to the conclusion that gold color symbolizes wealth, prestige, and successful life. The Color Symbols that represent the American Dream

\section{Green, White and Gold: the Symbols of American Dream}

The first color, green, symbolizes the hope for happiness. For Gatsby the green light is the symbol of his hope to be with Daisy. Refering to Adams (1931:214-215), "the American Dream is that dream of a land in which life should be better and richer and fuller for everyone, with opportunity for each according to ability or achievement." Gatsby's hope is the dream that he wants to achieve, and Gatsby has a firm ambition to get what he wants in his life and his love.

As stated by Smith, for people who believe in the American Dreams, anything is attainable through hard work (2003:1). For Gatsby, his dream is to be with Daisy. Gatsby believes that through his hard work he will finaly get what he dreams of: Daisy. Gatsby was a poor man when he, for the first time, fell in love with Daisy. As a man of lowerclass, he realized that he could not get Daisy until he met Dan Cody who taught him a lot how to be a wealthy and high-class man. From then on, Gatsby has found a great opportunity in his life. It is described in the story that when Gatsby met Dan Cody for the first time, Gatsby was wearing the torn green jersey.

In the description of the green Sound, green water symbolizes the distance that Gatsby must reach in order to pursue his dream. The fact that this distance does not make Gatsby give up in his effort to pursue his dream shows his optimism and his selfreliance which, according to Emerus (1976: 83) is the base for American Dream. It is selfreliance that keeps Gatsby's hope alive.

Gatsby's hope, effort, and self-reliance is similar to those of the early settlers of America that had come to Long Island long before the term of American Dream was born. The aspects of the American Dream are the pursuit of happiness, self-reliance, and the way to wealth (Bouti, 2013:1).

The second color, white, symbolizes wealth, one of the most pursued American Dreams. Warshauer (2003) states that dominantly the Americans try to achieve three kinds of American Dreams: fame, wealth, and success. White palaces and white windows describe the Buchanans' wealth. Daisy is also described wearing a white dress when Nick comes to the Buchanans' house to meet Daisy. Jordan's white dress also represents the wealth, success, and fame. White as a symbol of wealth can also seen through white flannel suit that Gatsby wears. Considering that wealth, fame, and success are the most pursued American Dreams, white can be said as the symbol of the American Dreams.

The third color, gold, symbolizes wealth, prestige and successful life. Gold is mentioned for the first time in the novel to desrcibe Jordan Baker's (a famous and successful golf athlete) golden arms and golden shoulder. Gold is identical with Jordam Baker's success, one of most desired American Dreams.

Gold color is mentioned again in the gold-colored tie. It represents the wealth and the prestige of the present Gatsby, a wealthy high-class man, who is completely different from the poor Gatsby in the past, when he 
was nobody with no money. In addition, color of the toilet set in Gatsby's room is gold. All of these things represent material prosperity and success whis is the result of one's hard work.

\section{Concluding Remark}

In reading The Great Gatsby, readers should carefully and critically observe the use of colors. In this brief study, the colors of green, white, and gold prove to be colors that are associated and, therefore, represent the idea of the American Dreams.

Green (the green light, the green leather conservatory, the green-house, the applegreen shirts, the green jersey, the green card, the green Sound, and the green breast of the new world) symbolizes hopes or dreams, i.e. the dream of a better and richer land. The dreams or hopes in the story is achieved by hardwork as suggested by the American Dream: anything is attainable through hard work. White (the white palaces, the white dress, the white windows, the white roadster, the white card and the white flannel suits) is associated with th idea of the American Dream, which is the achievement on success, fame and wealth. Gold (the golden arms, the golden shoulder, the gold-colored tie, and the toilet set of pure dull gold color) symbolizes wealth, prestige and successful life. Wealth (material prosperity) is one of the ideals that the people pursue most.

\section{References}

Abrams, M. H. A Glossary of Literary Terms. 4th ed. New York: Harcourt Brace Jovanovich College, 1981.

Adams, James Truslow. The Epic of America. Boston: Little, Brown, 1931.

Arp, Thomas R., and Greg Johnson. Perrine's Literature: Structure, Sound, and Sense. 7th ed. Fort Worth: Harcourt Brace College, 1998.
Bouti, Suleman. "American Dream in F. Scott Fitzgerald's the Great Gatsby". Jurnal Inovasi. Vol.4. No.1 (2013): pp.1-9. UNG Repository. Web. 2 July 2015. </repository.ung.ac.id/get/karyailmiah/ 169/american-dream-in-f-scottfitzgeralds-the-great-atsby.pdf>

Bortoli, Mario de, and Jesus Maroto. "Colours Across Cultures: Translating Colours in Interactive Marketing Communications". Global Propaganda. University of Paisley. 2001. Web. 2 July 2015 <globalpropaganda.com/articles/Transl atingColours.pdf $>$

Cullen, Jim. The American Dream a Short History of an Idea That Shaped a Nation. Oxford : Oxford University Press, 2003.

Degler, Carl N. Out of Our Past. New York: Harper and Row, Inc., 1962.

Fitzgerald, F. Scott. The Crack-up: With Other Pieces and Stories. Harmondsworth, Middlesex : Penguin, 1965.

Fitzgerald, F. Scott. The Great Gatsby. Adelaide: The University of Adelaide Library. Web. 11 June 2014. <ebooks.adelaide.edu.au>

Guerin, Wilfred L., Earle Labor, Lee Morgan, Jeanne C. Reesman, and John R. Willingham. A Handbook of Critical Approaches to Literature. 6th ed. New York: Oxford University Press, 2011.

Guth, Hans P. and Gabrielle L. Rico. Discovering Literature: Stories, Poems, Plays. Englewood Cliffs: Blair Press Book,1997.

Hall, Stuart. Representation: Cultural Representations and Signifying Practices. London: SAGE Publication Ltd, 2003.

Hawkes, Terence. Structuralism \& Semiotics. Reprinted. London: Menthuen Co.Ltd, 1978. 
Holman, C. Hugh, William Flint Thrall, and William Harmon. A Handbook to Literature. $5 \mathrm{~d}$ ed. Michigan: Macmiller, 1986.

Krauzer, Michael. "What Does the Color Gold Mean or Symbolized in the Bible." Web. 1 July 2015. <patheos.com/blogs/christiancrier/201 4/11/03/what-does-the-color- goldmean-or-symbolize-in-the-bible/).

Merriam-Webster. Web. 2 July 2015. $<$ merriam-webster.com> "Nation at the Crossroads: The Great New York Debate over the Constitution, 1787-88 ." The Declaration of Independence. By the Continental Congress at Independence Hall, Philadelphia, July 4th 1776, And Acknowledged by the Whole World in the Centennial Year 1876. 1983. Web. 1 July 2015. <nyhistory.org/web/crossroads/>

Oxford Dictionaries - Dictionary, Thesaurs, \& Grammar. Web. 2 July 2015. $<$ oxforddictionaries.com>

Perry, Ralph Barton and Ralph H. Gabriel. Characteristically American. New York: Knopf, 1949.

Roberts, Edgar V. and Henry E. Jacobs. Fiction: An Introduction to Reading and Writing. 3th ed. Upper Saddle River: Prentice Hall, 1991.

Rohrberger, Mary, and Samuel H. Woods. Reading and Writing about Literature. New York: Random House, 1971.

Samkanashvili, Maia."Uses of Symbols and Colors in The Great Gatsby by F. Scott Fitzgerald". Journal of Education. Vol.2. No. 1 (2013): pp.31-39. IBSU. Web. 1 July 2015.

<journal.ibsu.edu.ge/index.php/sje/ article/view/449).

Smith, S.E. "Defining The American Dream." Google Docs. Web. 1 july 2016. $<$ docs.google.com/document/d/1Bxdfl7 V0opJc2ya3MIoDqUhE4zH9pMfl74GmXy j1QmU/edit?hl=en_US\&pli=1)
Stanton, Robert. An Introduction to Fiction. New York, NY: Holt, Rinehart and Winston, 1965.

Strba, Ivan. Birth, Life and Disillusionment of the American Dream in the Great Gatsby. Undergraduate Thesis. Slovakia: Presov University, 2012.

Taghizadeh, Ali. "Theory of Literary Structuralismin Henry James)". Theory and Practice in Language Studies. Vol.3. No.2. (2013): p.288. Academy Publisher. Web. 3 July 2015 <ojs.academy publisher.com/index.php/tpls/article/vi ew/tpls0302285292/62 88).

Thompson, Benjamin F. History of Long Island: Containing an Account of the Discovery and Settlement : With Other Important and Interesting Matters to the Present Time. New York: E. French, 1839.

Vaughn-Kelso, Katie, Christine Breese D.D., Ph.D., and Casey Carothers. "The Meaning of Colors." Spiritual Symbols \& Colors. (2005): pp.87-96. Starlight Journal. Web. 3 July 2015. <starlightjournal.com/Storefiles/Symbol sAndColors/SymbolsAndCol ors.pd>

Warshauer, Matthew. "Who Wants to be a Millionaire : Changing Conceptions of the American Dream" Liverpool: John Moores University. 2003.

Wellek, Rene, and Austin Warren. Theory of Literature. New York: Harcourt, Brace, 1962.

Zettl, Herbert. Sight, Sound, Motion: Applied Media Aesthetics. Belmont: Wadsworth Publisher, 1973. 